DOI: $10.17516 / 1997-1370-0698$

УДК 81’272

\title{
Discursive Strategies \\ of Legitimating Institutionalized Values \\ in Educational Settings: \\ Experience of Japan
}

\author{
Anastasia V. Kolmogorova and Anna V. Kozachina* \\ Siberian Federal University \\ Krasnoyarsk, Russian Federation
}

Received 02.10.2020, received in revised form 19.10.2020, accepted 07.12.2020

\begin{abstract}
The current paper focuses on the strategic aspect of discursive practice of transferring, legitimizing and reproducing institutionalized values in students' worldview with a subsequent transformation into the cultural scripts. The study is based on $T$. van Leeuwen's theory of the legitimation strategies. Researcher defines four major categories of strategies used in legitimizing: authorization, moral evaluation, rationalization, mythopoesis. Studying a process of legitimation in educational settings on the example of Japan illustrates the procedure of linguistics transfer of institutionalized values through various discourses and exposes language tools for social control. The results provide an opportunity to study the process of linguistic transfer of institutionalized values and their transformation into the cultural scripts in Russian discourse.
\end{abstract}

Keywords: legitimation, strategies of legitimation, institutionalized values, educational settings, Japan, education in Japan, Japanese curricula.

Research area: linguistics.

Citation: Kolmogorova, A.V., Kozachina, A.V. (2020). Discursive strategies of legitimating institutionalized values in educational settings: experience of Japan. J. Sib. Fed. Univ. Humanit. Soc. Sci., 13(12), 1985-1994. DOI: 10.17516/1997-1370-0698.

(C) Siberian Federal University. All rights reserved

* Corresponding author E-mail address: avkozachina@gmail.com

ORCID: 0000-0002-6425-2050 (Kolmogorova); 0000-0001-7831-0357 (Kozachina) 


\section{Introduction}

Values are among the most studied basic constructs in psychology, philosophy and social sciences. The term value is polysemous. One definition of basic human values which has been very influential is that of F. Kluckhohn who defines a value as "a conception, explicit or implicit, distinctive of an individual or characteristic of a group, of the desirable which influences the selection from available modes, means and ends of action" (Kluckhohn, 1951: 395). Values penetrate all areas of our life, human relations, politics, economics, religion, etc. Some are universally shared, and some are peculiar to the specific type of civilization or ethnos. Values can be personal or reflect specific social group or institute and most interestingly might be institutionalized in accordance with prevailing ideology.

This paper will focus on studying the phenomenon of institutionalized values, influenced by theory of T. Parsons who was concerned with the way moral values from the cultural system become internal regulators of conduct and motivation (Parsons, 1964). Moreover, we take into account the view of R. D'Andrade, one of the founders of cognitive anthropology who defined institutionalized values as characteristics of institutions that are collectively agreed upon value criteria that apply to role performance (D'Andrade, 2008: 122-123). Building on the experience of these researchers we define institutionalized values as a set of moral, ideological, religious, aesthetic attitudes and dominant cultural dimensions of particular community that responds the interests of an institutional authority, which attempts to reproduce them in the worldview of each member as a guideline of a social behaviour.

It is the USSR policy that is a particularly striking example of values' institutionalization. During the Soviet period, patriotic spirit was supposed to be a main value and a core factor of national consolidation; therefore, designing the image of "Motherland" and fostering of patriotism received special attention. The most significant tools of legitimation and implementation of values were the school textbooks of history (Konkka, 2019: 50). Much has changed since then - nationally and internationally. The breakup of the USSR caused a shift in ideology and raised a question of what values should be produced and transmitted through the educational settings in the era of globalization.

From September 1, 2012, the course of "Fundamentals of Religious Cultures and Secular Ethics" was introduced in all constituent entities of Russian Federation. It is aimed to introduce to younger generation basis of moral and ethics and form the ability to respect the religious traditions of multinational people of Russia, as well as to construct the dialogue with other cultural groups.

Another country that faced extensive changes in the $20^{\text {th }}$ century is Japan. A sharp turn from policy of fascism and militarism towards democracy and globalism inspires us to study Japan's experience in constructing new generations' worldview.

The focus of our research is text corpus of the Moral Education Course that is considered as an integral part of educational setting in Japan. The course is designed by The Ministry of Education, Culture, Sports, Science and Technology (MEXT) and aimed at transferring, legitimizing and reproducing a certain set of institutionalized values in students' worldview with a subsequent transformation into the cultural scripts. Values highlighted in the Course are selected and interpreted in accordance with institutional authority. This process is carried out with a specific discursive practice which has its own genres, strategies and means.

In the current paper we focus on the strategic aspect. Studying a discursive practice of legitimation in educational settings on the example of Japan we aim at describing the procedure of linguistics transfer of institutionalized values through various discourses and exposing universal communicative tools.

\section{Theoretical framework}

Education institution is one of social institutions along with political, economic and religious ones that form society. As A. Pennycook mentions, an optimistic liberal view of education is that it provides opportunity for all, yet it does not take a very sophisticated critical analysis to suggest that this is far from what actually happens (Pennycook, 2000: 93). Over 
the last years, increasing number of critical studies, especially in educational settings, has revealed that much of education can never be free of values and ideology (Toh, 2013: 1466). It is said that not only traditional values are expressed, but also the latest societal and global trends, including globalization, internationalization, marketization, neoliberalism and commoditization (Kubota, McKay, 2009).

Social control and authority reproduction are maintained in educational settings. T.A. van Dijk argues that one important condition for the exercise of social control through discourse is the discourse control and discourse production itself (Dijk, 2008: 31). Powerful groups tend to use different agents whom the recipients of discourse perceive as authorities. In relation to educational settings those are teachers who play the mediating role in discourse acting in accordance with the recommendations of the institutional authorities.

Written discourse is, for the most part, explicitly programmed or planed, and therefore, better controlled (Dijk, 2008: 54). It is expressed most forcefully in educational settings, whereas school, college or university lessons are unthinkable without textbooks or other written materials. Therefore, discourse analysts concentrate not only on teachers' conversation strategies and positioning in the dialogues inside the classroom (Matre, Solheim, 2016), but on curriculums and approaches to curriculum design in public schools (Apple \& Christian-Smith, 1991; Pennycook, 2000; Kubota, McKay, 2009; Toh, 2013).

In this sense the institutional authorities need special means to control authority reproduction and value transfer in discourse. One of them is called legitimation.

The belief that a rule, institution, or leader has the right to govern is commonly defined in political science and sociology as "legitimacy" (Encyclopedia Princetoniensis). The act of providing legitimacy is commonly called legitimation.

Since the second half of the $20^{\text {th }}$ century this phenomenon has been extensively studied within several research areas and the number of relevant studies has grown rapidly and in a variety of directions. Some scholars examine legitimacy not only from the perspective of sociology, but from the legal sciences defining it as "legalization" (in studies of M. Dogan, A. Vidic). The phenomenon of legitimation is also reflected in studies of economics, business and management (in studies of S. Bork, D. L. Deephouse, M. Huber, T. Saretzki, J. P. L. Schoormans, C. Sica, M. Suchman, H. Walker, M. Zelditch). The increasing impact of the Internet and Media on modern society also draws scholars' attention to legitimation process in the online space (in studies of L. Garcia, E. Josserand, C. E. Howell, M. Kneuer, A. Laifi, J. A. Lischka, M. Matthews, F. Silva).

A relatively large group of researchers identify the sociopolitical context of legitimacy as priority for analysis (in studies of P. Berger, P. Bourdieu, T. J. Dowd, C. Johnson, T. Luckmann, C. L. Ridgeway, A. V. Skiperskih, M. Suchman, K. Thyen, M. Weber).

In subsequent years, the term "legitimation" has incorporated in linguistic studies (Vaara, Tienari, Laurila, 2006; Vaara, Monin, 2010; Joutsenvirta, Vaara, 2015; Dijk, 2008; Leeuwen, 1995, 2008; Fairclough, 2013; Kolmogorova, 2018). Following the principles of sociological theory, critical discursive analysts emphasize the multifaceted nature of legitimacy and focus on discursive and ideological practices by which legitimation is carried out.

Most reviewers credit Max Weber who defined legitimacy as a justified right to exist that any formal system of organization or "domination" needs (Weber, 1948). According to the approach of Peter L. Berger and Thomas Luckmann, legitimation is the third stage of the institutionalization process (Berger \& Luckmann, 1991). The institutional world requires legitimation as a way by which it and its practices can be "explained" and justified (Berger \& Luckmann, 1991: 72). A broad range of studies evidence a strong connection between legitimation and institutionalization (in studies of H. E. Aldrich, C. M. Fiol, T. Kostova, M. Suchman, E. Vaara, S. Zaheer). However, it is a subject of debate among the analysts.

In a critical discursive perspective legitimation is related to ideology (Leeuwen, Wodak, 1999), social structures and discursive events (Fairclough, 2005), power relations 
(Dijk, Rojo, 1997) and textual practices and strategies through which legitimation is carried out (Leeuwen, Wodak, 1999; Fairclough, 2003; Leeuwen, 2008; Vaara, Tienari, Laurila, 2006; Vaara, Monin, 2010; Joutsenvirta, Vaara, 2015). From this perspective legitimation is considered to be a discursive process creating senses of legitimacy or illegitimacy in the texts and social contexts (Joutsenvirta, Vaara, 2015: 744). This leads to the conclusion that legitimation as a discursive practice can be seen as a means of implementation of social control as well. Since legitimation is one of the core constructs of social reality it takes place under different discourses.

The number of studies focused on discursive practices and legitimation through the educational settings has dramatically increased in recent years. Thus, from a CDA perspective, the educational settings have a specific role in the process of legitimation because "students are obliged to be recipients of discourse: lessons, learning materials, instructions need to be attended to, interpreted and learned as intended by institutional or organizational authors" (Giroux, 1981).

Discourse analyst T. van Leeuwen studying English discourse on the tradition of critical linguistics created a corpus of texts named "The first day of school". It includes a wide range of the text types - books for very young children, brochures for parents, media reports, advertisements for school gear, teacher training texts, reminiscences in short stories and novels (Leeuwen, 2008: 6). Having analysed how legitimation is constructed in English discourse, T. van Leeuwen identified four major categories of legitimation strategies:

1. Authorization. A strategy that is being implemented by reference to the authority of tradition, custom, law, and/or persons whom institutional authority of some kind is vested in.

2. Moral evaluation. A strategy that is being implemented by reference to value systems.

3. Rationalization. A legitimation by reference to the goals and uses of institutionalized social action and to the knowledge that society has constructed to endow it with cognitive validity.
4. Mythopoesis. A strategy that is conveyed through narratives whose outcomes reward legitimate actions and punish nonlegitimate actions (van Leeuwen, 2008).

The validity of defined strategies can be proved by numerous discursive studies of legitimacy based on different social practices across countries (in studies of F. Coban Doskaya, T. Goessens, I. Ieţcu-Fairclough, A. V. Kolmogorova, V. Jalali, B. Sadeghi). All of them are considered as reliable tools that make it possible to expose the dominant ways to legitimate values promoted by the authorities.

\section{Statement of the problem}

Under the dynamism of global communications, the education policy in non-European countries is of the great interest due to the enormous role of traditions that even today transform the younger generation values. In current research we refer to the educational settings of modern Japan. The present Basic Act on Education states that education should "cultivate morality and ethics" (Basic Act on Education).

The focus of our study is the texts corpus of the Moral Education Course that represents Japanese modern educational system. First introduced in 1958 by the Ministry of Education, Culture, Sports, Science and Technology (MEXT), the Course became an integral part of the curriculum of formal schools in 1962 and is still implemented in educational process today (Takashi, 1990: 32). It consists of the set of textbooks called 私たちの道徳 /watashi-tachi no do:toku/ ("Our moral") and the curricula for teachers of elementary and secondary schools. This corpus contains a variety of moral values which are selected by the Ministry of Education and clearly categorized in the following way:

1. About the self.

2. About relationships with other people.

3. About groups and society.

4. About relationships with nature and sublime (Bamkin, 2016: 7).

The complete list of values is to be found in the curricula for teachers on MEXT official website. Teachers are to plan their lessons according to this system. 
Analysis of this texts' corpus formed the basis of dynamic model of legitimizing institutionalized values (see Fig. 1).

This model illustrates the way institutionalized values are being transferred, legitimized and reproduced in students' worldview within the discourse of educational settings and transformed into the cultural scripts that differ depending on the society and culture. The Ministry of Education acting as an institutional authority produces institutionalized values and incorporates them in the text of curricula and textbooks which are designed in harmony with the existing ideology. A teacher, as a mediator, organizes educational process drawing on the recommendations of the institutional authority. In the process of interaction a teacher and a school student become actors of legitimation practice in both oral and written discourses. Legitimation practice is constituted by strategies implemented within genres that differ according to the type of discourse. As a result, the institutionalized values are reproduced in the cognitive experience of younger generation in the form of cultural scripts that determine the behaviour of an individual in other discourses.

In this paper we concentrate on the strategic aspect of the discursive practice, due to the fact it plays a major role in the process of implementation and language transfer of the institutionalized values. We describe the realization of legitimation practice in educational settings of Japan on the example of the value 節 度/setsudo/ ("modesty").

\section{Methods}

In order to uncover the specific features of legitimation practice in educational settings we used the method of discourse analysis and also the CDA (critical discourse analysis) - a type of discourse analytical research that primarily studies the way social power abuse, dominance, and inequality are enacted, reproduced, and resisted by text and talk in the social and political context (Hamilton, Schiffrin, Tannen, 2001: 352). The etymological analysis and the elements of cultural linguistics method tend to reveal the roots of institutionalized value 節度 /setsudo/ (“mod-

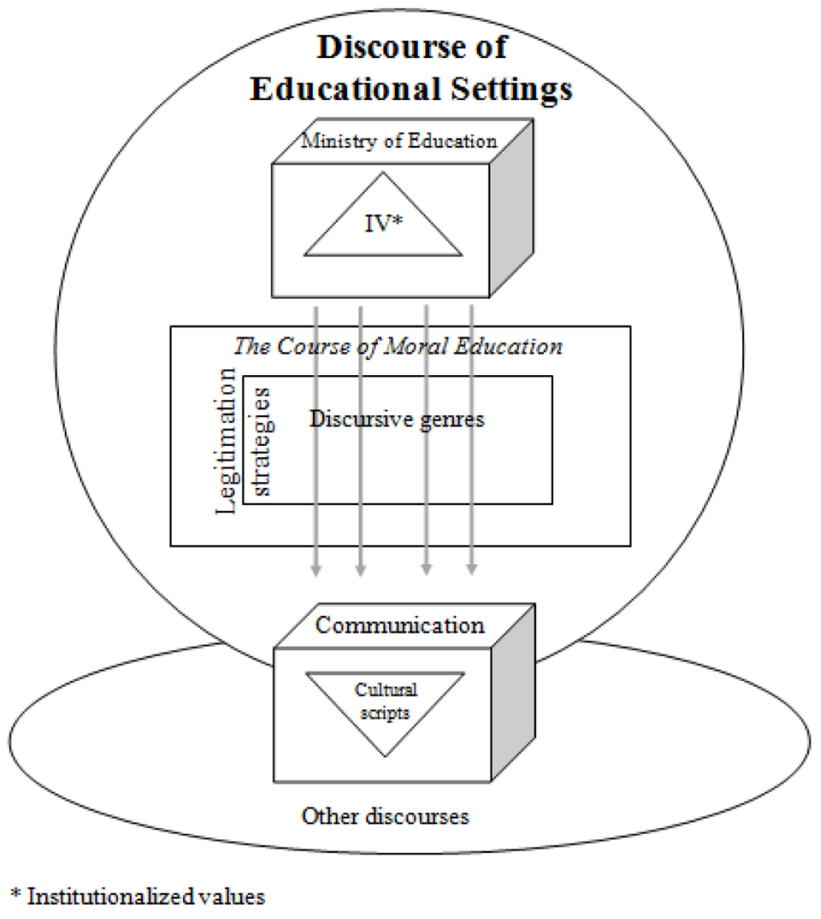

Fig. 1. Dynamic model of legitimizing institutionalized values 
esty"). The volume of reviewed material is more than 1500 pages.

\section{Results}

The token 節度 /setsudo/ (“moderation”) consists of two hieroglyphics. 節/setsu/ means "node, season, period, occasion" and 度 /do/ means "degrees, occurrence, time".

This institutionalized value setsudo has a possible link to a Neo-Confucian tradition that became the official state ideology doctrine in the $17^{\text {th }}$ century (the Edo period). The social aspects of Neo-Confucian are focused on the filial piety. This created a new social stratification in Japanese society that previously had not existed. This stratification divided it into four main classes: the samurai, seen as the Japanese equivalent of the Chinese scholar-bureaucrats, at the top of the social hierarchy, then the farmers, artisans, and merchants (Craig, 1998: 553). Setsudo is also rooted in the principle of enryo ("reserve; constraint; restraint; moderation"). Enryo is a Japanese culture-specific regulative tool that emphasizes self-restraint in one's expression of opinion, maintenance of the harmony within a group, neglect of the interests of the individual (Blaker et al., 2002: 9).

Japanese children learn from their earliest days that human fulfillment comes from close association with others and not from selfishness. Children learn to early recognize that they are part of an interdependent society beginning in the family and later extending to larger groups such as neighbourhood, school, community, and workplace (Dolan, Worden, 1992: 94). In this regard moderation is one of the most significant principles of Japanese communication.

Further we will consider the implementation of this institutionalized value through van Leeuwen's legitimation strategies.

1. Authorization. The most frequent forms found in the textbooks are an appeal to personal and role model authority.

In the case of personal authority, legitimate authority is vested in people because of their status or role in a particular institution (Leeuwen, 2008: 106). Legitimacy is provided by quotes of both Japanese and foreign scien- tists, philosophers, politicians, artists, writers and cultural figures whose status is undisputed in discourse.

Personal authority legitimation typically takes the form of a "verbal process" clause in which the "projected clause" contains some form of obligation modality (Leeuwen, 2008: 106). As in the following example 1 the quote of Quintus Horatius Flaccus, translated into Japanese, contains the obligative form of verb 守る/mamoru/ ("to save", "to abide", "to follow”) - 守れ/mamore/:

(1) 何事にも節度を守れ。何事にも中央が あり、その線が適切のしるしなのだから。

Follow the principals of moderation in everything. Everything has a midpoint, and that line is an appropriate way (c) Quintus Horatius Flaccus.

In the case of role model authority, people follow the example of role models or opinion leaders. The role models in textbooks are ordinary school students who legitimate "right" behaviours and delegitimate "anomaly" through their statements.

（2）お菓子を食べ過ぎしてしまったな。夕 ご飯が食べられないよ。

Well, I've been eaten too much sweets. I can't eat dinner!

In the example 2 the schoolgirl regrets for eating so many sweets that she cannot eat dinner with her family. Unlike the previous example there is no explicit reference to moderation setsudo, but it is implicitly messaged by auxiliary verbs 過ぎる/sugiru/ added to the stem of a verb食べる/taberu/ (“to eat") to express excessiveness and しまう/shimau/ to express an action that is done or happened unintentionally.

2. Moral evaluation strategy. Moral evaluation legitimation is based on values; in some cases, moral value is simply asserted by words such as "good" and "bad", but in most cases moral evaluation is linked to specific discourses of moral value by means of evaluative adjectives such as "normal", "useful", "healthy" and so on (Leeuwen, 2008: 109-110). In textbooks we revealed the following adjectives: 大切な / taisetsuna/ ("important"; "necessary”), 必要な /hitsuyo:na/ ("necessary"; "needed"; "essential”), 大事な /daijina/ (“important"; "serious"; "crucial"). 
(3) 基本的な生活習慣をしつかりと身につ けることは、生活をしていく上で、大切なこと です。

It is important to implement fundamental lifestyle habits in your daily life.

To a great extent, Japanese usually do not operate the concepts of good or bad, preferring "important" or "required". These categories are the integral part of the cultural model of Japanese behaviour, the "shame culture". The term which was originally applied by Ruth Benedict (Benedict, 1989) explains the fundamental contrast in the psychological makeup of Japanese and Americans. In contrast to guilt culture, in which a person knows if he or she is good or bad by feeling, in a shame culture good or bad behaviour depends on the community whether other people accept or exclude it.

3. Rationalization strategy. T. van Leeuwen distinguishes two main types of rationality. Instrumental rationality legitimizes practices by reference to their goals, uses, and effects, while theoretical one legitimizes practices by reference to a natural order of things through definition, explanation and prediction (Leeuwen, 2008: 113). This is reflected in the discursive genres such as "advice" and "instruction".

We will review rationalization strategy in Japanese educational settings by goal orientation, means orientation and definition forms.

In the case of goal orientation purposes are constructed on a formula "I do $\mathrm{x}$ in order to do (or be, or have) y" (Leeuwen, 2008: 114). In Japanese it is based on the grammatical construction ために/in order to/ in subordinate clause that refers to the objective of an action and appends to verbs that includes volition. The main clause contains: 1) necessitative construction 〜なければならない/nakerebanaranai/ ("must"); 2) the infinitive constructions that illustrate modality.

（4）自分の健康のため：朝ごはんをしつ かりと食べる。好き嫌いなく食べる。

For the health: to eat breakfast well, to eat without likes and dislikes.

In the case of means orientation, the purpose is constructed on the formula "I achieve doing (or being, or having) y by x-ing," which leaves the agency intact and uses circumstances of means with "by", "by means of", "through", etc. (Leeuwen, 2008: 115). In Japanese we identified a compound particles こと で/koto de/ ("by doing this"), として/to shite/ ("in the role of") and によって/ni yotte/ ("by means of; due to") (Makino \& Tsutsui, 1995).

(5) 節度をもつて生活していくことで、気持 ちの良い毎日を過ごすことができる。

Bybeing moderate, you can spend a pleasant day.

In the example (5) the institutionalized value setsudo operates as a mean of achieving happiness and delight.

The definition is the form, in which one activity is defined in terms of another moralized activity. Both activities must be objectivated and generalized, and the link between them must be either attributive ("is", "constitutes", etc.) or significative ("means", "signals", "symbolizes", etc.) (Leeuwen, 2008: 116). In Japanese it is represented by topic marker は/wa/ (or とは/towa/), a grammatical particle placed after whatever is to be marked as the topic.

(6) 節度とは、行動などがちょうど良い程 度のことです。

Moderation is a sense of proportion in your actions.

Such statements function as axioms referring forward to the more detailed activity to which they are hyponymically related. The statement from the example 6 also refers to everyday discourse and recalls the importance of the principle of moderation in lifestyle.

\section{Mythopoesis strategy}

Legitimation can also be achieved via discursive genre of tale. The main forms are moral tales and cautionary tales. In moral tales, protagonists are rewarded for engaging in legitimate social practices, in cautionary tales, on the other hand, protagonists engage in deviant activities that lead to unhappy endings (Leeuwen, 2008: 117-118). Textbooks "Our Moral" include a lot of tales which children read, discuss with classmates and a teacher. Such didactic stories transmit the moral and values of traditional Japan, such as modesty, courage, hardworking, respectfulness, etc. They also answer the questions after the text and write mini-essays where they try to express their opinion about the story they have read. 
We will review mythopoesis strategy on the example of cautionary tale "The Tale of the Fisherman and the Fish" that has been rendered as "Golden Fish". It is noteworthy that the tale is placed in the category よく考えて節度ある生 活を ("Let's live wisely and moderate") and is fully in line with the following regulation in the teacher's guidebook:

(7) 自分でできることは自分でやり, 安全 に気を付け, よく考えて行動し, 節度のある生 活をすること。

Do what you can do by yourself, be careful about safety, think carefully and live a modest life.

Throughout the whole story the old woman acts against the social model of legitimation "to be moderate". All of her whims are described using evaluative adjectives: あたらしい /atarashii/ ("new") - about a washtub; 綺麗な / kireina/ ("beautiful") - about new hut, 立派な /rippana/ ("admirable, elegant") - about outfit and palace.

Finally, the old woman asked the fish to make her "The Lady of the Sea", thus her behaviour leads to the well-known unfortunate consequences:

(8) おじいさんがおばあさんのところへ帰 ると、元のような粗末な小屋の前で、おばあさ んがぼんやり座っていました。

He went back to his hut, the old woman was sitting outside and before her lay a broken washtub.

After reading the tale, children are invited to reflect on the following question and discuss it with the classmates: Why did the fish "reply not a word, just slapped her tail on the water and dived deep into the blue sea"?

And it is important to remember the role of the teacher, who not only listen to the school student's thoughts but also direct them to the right conclusion that is relevant to the institutionalized value 節度 /setsudo/.

To summarize, in our research we studied one of the institutionalized values of the Moral Education Course - 節度 /setsudo/. This value dates back to Neo-Confucian tradition that was the official state ideology doctrine in the $17^{\text {th }}$ century. In spite of the fact that setsudo refers to the group of traditional values, the analysis demonstrates that the mechanisms of legitimizing are arguably the same as the ones presented in T. van Leeuwen's research. It shows the impact of globalization and proves that all the legitimation strategies identified by T. van Leewen could be considered as universal tools for maintaining control in discourse regardless of linguoculture.

\section{Conclusion}

The institutionalized values differ significantly between cultures, nations and social classes. However, the impact of economic, political and social globalization and internationalization leads to the fact that the interaction between social actors acquires the universal features and authorities use the same mechanisms to control discourse. The results proved an opportunity to study how values are being transferred, legitimized, reproduced and transformed into the cultural scripts in Russian discourse as well.

\section{References}

Apple, M., Christian-Smith, L. (1991). The politics of the textbook. In The politics of the textbook, 1-19.

Bamkin, S. (2016). Moral education at Japanese elementary school. In Winston Churchill Memorial Trust, 4-32.

Basic Act on Education (2006). Available at: https://web.archive.org/web/20160331133057/http://www. mext.go.jp/english/lawandplan/1303462.htm (accessed 28 September 2020).

Benedict, R. (1989). The Chrysanthemum and the Sword: Patterns of Japanese Culture. Oxford, England, Houghton Mifflin, 324 p.

Berger, P., Luckmann, T. (1991). The Social Construction of Reality. A Treatise on sociology of Knowledge. London, Penguin Group Ltd., 250 p.

Blaker, M., Giarra, P., Vogel, E. (2002). Case studies in Japanese negotiating behavior. Washington, DC, US Institute of Peace Press, 224 p. 
Craig, E. (1998). Routledge Encyclopedia of Philosophy. New York, Routledge, 917 p.

D’Andrade, R. (2008). A Study of Personal and Cultural Values. New York, Palgrave Macmillan, 173 p. Dijk, T.A. (2008). Discourse and Power. London, Palgrave, 308 p.

Dijk, T.A., Rojo, L.M. (1997). 'There was a problem, and it was solved!': Legitimating the expulsion of 'illegal' migrants in Spanish parliamentary discourse. In Discourse \& Society, 8, 523-566.

Dolan, R.E., Worden, R.L. (1992). Japan: a country study. Washington, DC, Federal Research Division, Library of Congress, $610 \mathrm{p}$.

Encyclopedia Princetoniensis (2019). Available at: https://pesd.princeton.edu (accessed 7 September 2020).

Fairclough, N. (2005). Critical Discourse Analysis. In Marges Lingquistiques, 9, 76-94.

Fairclough, N. (2013). Critical discourse analysis and critical policy studies. In Critical Policy Studies, 7(2), 177-197.

Fairclough, N. (2003). Political correctness: The politics of culture and language. In Discourse and Society, 14(1), 17-28.

Giroux, H.A. (1981). Ideology, Culture \& the Process of Schooling. Philadelphia, Pennsylvania, Temple University Press, $168 \mathrm{p}$.

Hamilton, H., Schiffrin, D., Tannen, D. (2001). The Handbook of discourse analysis. Cornwall, T.J. International, $874 \mathrm{p}$.

Joutsenvirta, M., Vaara, E. (2015). Legitimacy Struggles and Political Corporate Social Responsibility in International Settings: A Comparative Discursive Analysis of a Contested Investment in Latin America. In Organization Studies, 36(6), 741-777.

Kluckhohn, C.K. (1951). Values and value orientations in the theory of action. In Toward a general theory of action. Cambridge, Harvard University Press, 388-433.

Kolmogorova A.V. (2018). Legitimatsiya kak sotsiopoliticheskiy fenomen i ob"ekt diskurs-analiza [Legitimation as a Societal Phenomenon and as an Object of Discourse Analysis]. In Politicheskaya lingvistika [Political Linguistics], 1(67), 33-40.

Konkka, O. (2019). Iazyk postsovetskikh shkol'nykh uchebnikov istorii: dva urovnia legitimatsii politicheskogo v diskurse o proshlom [Language of history schoolbooks of the post-Soviet period: two levels of legitimation of the political settings in the discourse of past]. In Discurs legitimatsii: iazyk i politika $v$ epokhu global'nykh vyzovov [The Discourse of Legitimation: Language and Politics in a Time of Global Challenges], 50-69.

Kubota, R., McKay, S. (2009). Globalization and language learning in rural Japan: The role of English in the local linguistic ecology. In TESOL Quarterly, 43(4), 593-619.

Leeuwen, T. (2008). Discourse and Practice: New tools for critical discourse analysis. Oxford, Oxford University Press, $184 \mathrm{p}$.

Leeuwen, T., Wodak, R. (1999) Legitimizing immigration control: A discourse-historical analysis. In Discourse Studies, 1, 83-118.

Leeuwen, T. (1995). Representing social action. In Discourse \& Society, 6, 81-106.

Matre S., Solheim R. (2016). Opening dialogic spaces: Teachers' metatalk on writing assessment. In International Journal of Educational Research, 80, 188-203.

Parsons, T. (1964). Social Structure and Personality. New York, The Free Press, 376 p.

Pennycook, A. (2000). The social politics and the cultural politics of language classrooms. In The sociopolitics of English language teaching, 89-103.

Smith, R.J. (1983). Japanese society: Tradition, self and the social order. Cambridge, Cambridge University Press, $176 \mathrm{p}$.

Takashi, N. (1990). Moral education in Japanese public schools. In Moral Education Forum, 152, 27-36.

Toh, G. (2013). Critical Analysis of Discourse in Educational Settings. In The Encyclopedia of Applied Linguistics. Iowa State University, Blackwell Publishing Ltd. 2013. P. 1466-1471.

Vaara, E., Monin, P. (2010) A recursive perspective on discursive legitimation and organizational action in mergers and acquisitions. In Organization Science, 21(1), 3-22. 
Vaara, E., Tienari, J., Laurila, J. (2006). Pulp and paper fiction: On the discursive legitimation of global industrial restructuring. In Organization Studies, 27, 789-810.

Weber, M. (1948). From Max Weber. Essays in sociology. London: Routledge \& Kegan Paul.

Wierzbicka, A. (1997). Understanding cultures through their key words: English Russian, Polish, German, and Japanese. Oxford, Oxford University Press, 328 p.

\title{
Дискурсивные стратегии легитимации институционализированных ценностей в педагогическом дискурсе: опыт Японии
}

\author{
A.В. Колмогорова, А.В. Козачина \\ Сибирский федеральньй университет \\ Российская Федерация, Красноярск
}

\begin{abstract}
Аннотация. Настоящая статья посвящена изучению стратегического аспекта легитимации лингвистического трансфера институционализированных ценностей в педагогическом дискурсе. В фокусе исследования находится корпус текстов курса «Моральное воспитание», основу которого составляют тексты учебника «Наша мораль» и комментариев к рабочим программам для учителей японских школ младшей и средней ступени. Основой анализа стали предложенные известным дискурс-аналитиком Т. ван Леувеном четыре дискурсивные стратегии легитимации: стратегия апелляции к авторитету, стратегия моральной оценки, стратегия рационализации, мифопоэтическая стратегия. Полученные результаты доказывают универсальность предложенной модели вне зависимости от лингвокультуры и предоставляют лингвистический инструментарий для изучения аналогичных процессов в современном педагогическом дискурсе России.
\end{abstract}

Ключевые слова: педагогический дискурс, легитимация, стратегии легитимации, институционализированные ценности, Япония, образование в Японии, японские образовательные программы.

Научная специальность: 10.00 .00 - филологические науки. 